\title{
СТАН ЕРЕКТИЛЬНОЇ ФУНКЦІї У ЧОЛОВІКІВ ІЗ ПЕРВИННИМ ГІПОТИРЕОЗОМ
}

\author{
๑Н. В. Пасєчко, Т. І. Крицький, Л. В. Наумова
}

ДВНЗ «Тернопільський державний медичний університет імені І. Я. Горбачевського мОЗ України»

РЕЗЮМЕ. ОДним із найчастіших загальних хронічних розладів у чоловіків після 40-річного віку $є$ еректильна дисфункція (ЕД) - нездатність досягти та/або підтримувати ерекцію статевого члена, достатню для здійснення задовільного статевого акту.

Мета дослідження - оцінити еректильну функцію за шкалою «Міжнародний індекс еректильної функції- 15» у чоловіків з первинним гіпотиреозом, які перебували на стаціонарному та амбулаторному лікуванні в Тернопільській університетській лікарні.

Матеріал і методи. Аналіз стану еректильної функції у чоловіків із гіпотиреозом проводили з використанням опитувальника «Міжнародний індекс еректильної функції - 15» (МІЕФ-15). Обстежено 60 чоловіків із первинним гіпотиреозом віком від 21 до 75 років.

Результати. ЕД вірогідно частіше трапляється в пацієнтів із гіпотиреозом (43 із 60 чоловіків, 72,0\%), ніж у чоловіків із контрольної групи. Встановлено вірогідне зниження всіх інтегративних показників МІЕФ-15 у чоловіків із гіпотиреозом, порівняно з показниками осіб контрольної групи. Результати анкетування обстежених хворих вказують на гіпотиреоз як на прямий чинник, який негативно впливає на статеву функцію у чоловіків.

Висновки. Аналіз результатів анкетування МІЕФ-15 чоловіків із гіпотиреозом, ЕД та андрогенним дефіцитом виявив виражене зниження всіх показників еректильної функції в обстежених обох груп, порівняно з контрольною. Обчислення інтегративних показників стану статевої функції в обстежених із гіпотиреозом, андрогенним дефіцитом та ожирінням або нормальною масою тіла показало вірогідне зниження у них усіх параметрів, порівняно з контрольною групою.

КЛючОВІ СлОВА: первинний гіпотиреоз; еректильна дисфункція; ожиріння.

Вступ. Сексуальність чоловіка розглядають як комплекс біопсихосоціальних процесів. Підтримка відповідної статевої активності регулюється комплексом, який складається з нейроендокринної, судинної систем і метаболічних процесів [1]. Статева функція - важливий елемент нормального способу життя чоловіка. Між тим, статеві розлади спостерігають у понад 150 млн чоловіків в усьому світі, вони проявляються розладами всіх складових копулятивного циклу змінами статевого потягу, ерекцій, еякуляцій та оргазму [2].

Одним із найчастіших загальних хронічних розладів у чоловіків після 40-річного віку є еректильна дисфункція (ЕД) - нездатність досягти та/ або підтримувати ерекцію статевого члена, достатню для здійснення задовільного статевого акту [3]. Поширеність ЕД у загальній популяції становить 52 \% у чоловіків віком 40-79 років. При цьому частота і тяжкість ЕД зростають з віком і за наявності коморбідних станів, у тому числі й гіпотиреозу $[4,5]$.

Встановлена низка механізмів та порушень, асоційованих з розвитком ЕД у чоловіків, хворих на цукровий діабет: гіперглікемія, старший вік, вісцерально-абдомінальне ожиріння та інші складові метаболічного синдрому, вживання препаратів, які сприяють ЕД (діуретики, ß-блокатори), підвищений рівень кінцевих продуктів глікації, гіпогонадотропний гіпогонадизм $[6,7]$. Метаболічний синдром також $є$ одним з проявів поєднання су- динних чинників ризику розвитку ЕД, оскільки його компоненти відіграють важливу роль в патогенезі ЕД [8]. Судинні та неврологічні порушення - найважливіші чинники розвитку ЕД. При цьому мультиваріантний аналіз засвідчив, що більш вагомим чинником розвитку органічної ЕД у осіб з метаболічним синдромом $є$ судинний [9]. ЕД може бути раннім маркером атеросклерозу, серцево-судинних ризиків та субклінічних системних судинних захворювань [10].

Робіт, в яких безпосередньо досліджується взаємозв'язок регуляції гіпотиреозу та еректильної функції, в літературі вкрай мало [11, 12].

ЕД у хворих на гіпотиреоз в основному має артеріогенний характер, що підтверджується даними опитування, фармакодоплерографією та посткомпресійним тестом [13]. Крім того, у третини хворих артеріогенні порушення поєднувалися з низьким рівнем андрогенів у крові, майже у половини - з ураженнями вегетативної та соматичної іннервації статевого члена [13].

Мета дослідження - оцінити еректильну функцію за шкалою «Міжнародний індекс еректильної функції - 15» у чоловіків з первинним гіпотиреозом, які перебували на стаціонарному та амбулаторному лікуванні в Тернопільській університетській лікарні.

Матеріал і методи дослідження. Аналіз стану еректильної функції у чоловіків із гіпотиреозом проводили з використанням опитувальника «Міжнародний індекс еректильної функції - 15» 
Огляди літератури, оригінальні дослідження, погляд на проблему

(MІЕФ-15). Анкета складається із 15 запитань, відповіді на які дозволяють оцінити стан лібідо, еректильної функції, оргастичних відчуттів, задоволеності від статевого акту та загальної задоволеності статевим життям.

Для оцінки функціонального стану щитоподібної залози (ЩЗ) і статевої системи у пацієнтів визначали концентрацію тестостерону, естрадіолу $\left(\mathrm{E}_{2}\right)$ і тиреотропного гормону (ТТГ) у плазмі крові методом твердофазного імуноферментного аналізу стандартними наборами фірми "Vector-best".

Обстежено 60 чоловіків із первинним гіпотиреозом віком від 21 до 75 років. За результатами анкетування МІЕФ-15 еректильну дисфункцію діагностовано у 43 із них, що становить 72,0\%.

У контрольну групу увійшло 25 чоловіків віком від 21 до 58 років без сексуальних розладів та ознак андрологічної патології за даними об'єктивного, андрологічного, клініко-лабораторного, функціонального та інструментального обстежень.

Статистична обробка отриманих даних була проведена з використанням прикладних програм STATISTICA 10.0 (StatSoftInc.США). При порівнянні кількісних показників, які мають близький нормальний розподіл, результати представляли як середнє значення \pm стандартна помилка середньої $(\mathrm{M} \pm \mathrm{m})$, при цьому використовували t-критерій Стьюдента дисперсного аналізу. Для аналізу виду в розподілі застосовували критерії Шапіро-Уїлка. Дисперсії розподілів ознак оцінювали за допомогою F-критерію в процедурі дисперсійного аналізу ANOVA. Враховуючи невеликі об'єми вибірок, були використані непараметричні методи аналізу даних. Порівняння незалежних груп за кількісними ознаками здійснювали непараметричним методом 3 використанням U-критерію Манна-Уїтні (для двох груп). Порівняння залежних груп за кількісними ознаками здійснювали непараметричним методом з використанням критерію Вілкоксона. Статистично значущими вважали відмінності при $\mathrm{p}<0,05$.

Результати й обговорення. Отримані дані засвідчили, що ЕД вірогідно частіше трапляється В пацієнтів із гіпотиреозом (43 із 60 чоловіків, 72,0 \%), ніж у чоловіків із контрольної групи. Результати анкетування МІЕФ-15 хворих на гіпотиреоз наведено в таблиці 1.

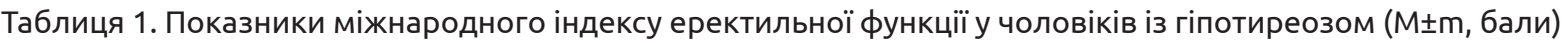

\begin{tabular}{|c|c|c|c|}
\hline Показник МІЕФ-15 & Контроль, $\mathrm{n}=25$ & Гіпотиреоз, n=60 & $p$ \\
\hline 1 - досягнення ерекції & $4,22 \pm 0,22$ & $3,53 \pm 0,14$ & $<0,01$ \\
\hline 2 - ерекція під час сексуальної стимуляції & $4,94 \pm 0,06$ & $3,79 \pm 0,14$ & $<0,01$ \\
\hline 3-достатність ерекції & $4,86 \pm 0,11$ & $3,27 \pm 0,14$ & $<0,001$ \\
\hline 4-збереження ерекції & $4,82 \pm 0,14$ & $3,16 \pm 0,16$ & $<0,001$ \\
\hline 5 - ерекція до закінчення статевого акту & $4,68 \pm 0,22$ & $3,77 \pm 0,15$ & $<0,01$ \\
\hline 6-кількість спроб здійснити статевий акт & $4,38 \pm 0,32$ & $3,18 \pm 0,17$ & $<0,01$ \\
\hline 7 - задоволеність статевим актом & $4,74 \pm 0,22$ & $3,25 \pm 0,17$ & $<0,01$ \\
\hline 8 - задоволення від статевого акту & $4,46 \pm 0,29$ & $2,98 \pm 0,16$ & $<0,001$ \\
\hline 9- частота еякуляцій & $4,46 \pm 0,24$ & $2,72 \pm 0,17$ & $<0,001$ \\
\hline 10 - частота оргазмів & $4,82 \pm 0,19$ & $3,37 \pm 0,16$ & $<0,001$ \\
\hline 11 - сексуальне бажання (частота) & $4,82 \pm 0,19$ & $3,17 \pm 0,17$ & $<0,001$ \\
\hline 12 - сексуальне бажання (ступінь) & $4,74 \pm 0,14$ & $3,49 \pm 0,16$ & $<0,001$ \\
\hline 13 - задоволеність статевим життям у цілому & $4,66 \pm 0,21$ & $3,34 \pm 0,15$ & $<0,01$ \\
\hline 14 - задоволення від сексуальних стосунків із партнеркою & $4,48 \pm 0,26$ & $3,11 \pm 0,14$ & $<0,001$ \\
\hline 15 - впевненість у досягненні та збереженні ерекції & $4,62 \pm 0,26$ & $3,19 \pm 0,17$ & $<0,01$ \\
\hline
\end{tabular}

Примітка. р - вірогідність різниці показників групи хворих на гіпотиреоз, порівняно з контролем, за критерієм Стьюдента.

Отримані дані виявили вірогідне зниження всіх інтегративних показників МІЕФ-15 у чоловіків із гіпотиреозом, порівняно з показниками осіб контрольної групи.

Результати анкетування обстежених хворих вказують на гіпотиреоз як на прямий чинник, який негативно впливає на статеву функцію у чоловіків. Крім порушення еректильної функції, у хворих на гіпотиреоз виявлено зниження як частоти виникнення, так і ступеня статевого бажання, а також погіршення оргастичних відчуттів у вигляді зменшення частоти сім'явивержень та оргазмів під час статевих контактів.

Означені порушення у чоловіків із гіпотиреозом призводять до погіршення як задоволеності безпосередньо статевим актом і, як наслідок, до зниження статевої активності, так і вдоволення статевим життям загалом, що є результатом зниження пацієнтом і самооцінки власних відчуттів від статевого життя, і оцінки стосунків із сексуальним партнером.

3 метою визначення впливу додаткових чинників, що впливають на стан еректильної функції 
Огляди літератури, оригінальні дослідження, погляд на проблему

чоловіків із гіпотиреозом, проаналізовано стан еректильної функції у 41 хворого з андрогенним дефіцитом (вміст тестостерону нижче 12 нмоль/л) і наявністю/відсутністю ожиріння за критерієм IMT>30 кг/M² за даними опитувальника МІЕФ-15.
Середні результати анкетування МIEФ-15 у чоловіків із гіпотиреозом та андрогенним дефіцитом залежно від наявності або відсутності ожиріння наведено в таблиці 2.

Таблиця 2. Показники міжнародного індексу еректильної функції у чоловіків із гіпотиреозом та андрогенним

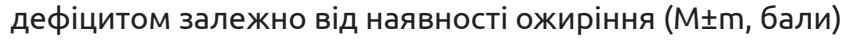

\begin{tabular}{|c|c|c|c|c|c|c|}
\hline Показник MIEФ-15 & $\begin{array}{c}\text { Контроль, } \\
n=25\end{array}$ & $\begin{array}{c}\text { Гіпотиреоз } 3 \\
\text { ожирінням, } n=26\end{array}$ & $\begin{array}{l}\text { Гіпотиреоз без } \\
\text { ожиріння, } n=15\end{array}$ & $\mathrm{p}$ & $\mathrm{P}_{1}$ & $\mathrm{P}_{2}$ \\
\hline 1 - досягнення ерекції & $4,22 \pm 0,22$ & $2,33 \pm 0,34$ & $2,82 \pm 0,25$ & $>0,05$ & $<0,001$ & $<0,001$ \\
\hline $\begin{array}{l}2 \text { - ерекція під час } \\
\text { сексуальної стимуляції }\end{array}$ & $4,94 \pm 0,06$ & $2,26 \pm 0,37$ & $2,82 \pm 0,32$ & $>0,05$ & $<0,001$ & $<0,001$ \\
\hline 3-достатність ерекції & $4,86 \pm 0,14$ & $2,27 \pm 0,35$ & $2,82 \pm 0,43$ & $>0,1$ & $<0,001$ & $<0,001$ \\
\hline 4 - збереження ерекції & $4,86 \pm 0,15$ & $2,16 \pm 0,35$ & $3,28 \pm 0,36$ & $<0,05$ & $<0,001$ & $<0,01$ \\
\hline $\begin{array}{l}5 \text { - ерекція до закінчення } \\
\text { статевого акту }\end{array}$ & $4,68 \pm 0,22$ & $2,21 \pm 0,33$ & $2,89 \pm 0,35$ & $>0,05$ & $<0,001$ & $<0,01$ \\
\hline $\begin{array}{l}\text { 6-кількість спро6 } \\
\text { здійснити статевий акт }\end{array}$ & $4,38 \pm 0,33$ & $2,73 \pm 0,36$ & $2,95 \pm 0,27$ & $>0,5$ & $<0,01$ & $<0,01$ \\
\hline $\begin{array}{l}7 \text { - задоволеність } \\
\text { статевим актом }\end{array}$ & $4,74 \pm 0,22$ & $2,26 \pm 0,26$ & $2,89 \pm 0,34$ & $>0,05$ & $<0,001$ & $<0,01$ \\
\hline $\begin{array}{l}8 \text { - задоволення від } \\
\text { статевого акту }\end{array}$ & $4,46 \pm 0,29$ & $1,98 \pm 0,34$ & $2,920 \pm 0,35$ & $<0,05$ & $<0,001$ & $<0,01$ \\
\hline 9- частота еякуляцій & $4,49 \pm 0,28$ & $2,79 \pm 0,34$ & $3,22 \pm 0,36$ & $>0,2$ & $<0,01$ & $<0,01$ \\
\hline 10 - частота оргазмів & $4,82 \pm 0,19$ & $2,96 \pm 0,34$ & $3,75 \pm 0,39$ & $>0,05$ & $<0,001$ & $<0,05$ \\
\hline $\begin{array}{l}11 \text { - сексуальне бажання } \\
\text { (частота) }\end{array}$ & $4,82 \pm 0,19$ & $3,58 \pm 0,34$ & $4,22 \pm 0,33$ & $>0,5$ & $<0,01$ & $>0,05$ \\
\hline $\begin{array}{l}12 \text { - сексуальне бажання } \\
\text { (ступінь) }\end{array}$ & $4,74 \pm 0,13$ & $2,79 \pm 0,29$ & $3,95 \pm 0,33$ & $<0,05$ & $<0,01$ & $>0,05$ \\
\hline $\begin{array}{l}13 \text { - задоволеність } \\
\text { статевим життям у цілому }\end{array}$ & $4,66 \pm 0,21$ & $2,74 \pm 0,34$ & $3,62 \pm 0,26$ & $<0,05$ & $<0,01$ & $<0,01$ \\
\hline $\begin{array}{l}14-\text { задоволення від } \\
\text { сексуальних стосунків із } \\
\text { партнеркою }\end{array}$ & $4,46 \pm 0,28$ & $2,74 \pm 0,34$ & $3,62 \pm 0,35$ & $<0,05$ & $<0,01$ & $>0,05$ \\
\hline $\begin{array}{l}15 \text { - впевненість у } \\
\text { досягненні та збереженні } \\
\text { ерекції }\end{array}$ & $4,62 \pm 0,29$ & $2,39 \pm 0,33$ & $3,35 \pm 0,35$ & $<0,05$ & $<0,001$ & $>0,05$ \\
\hline
\end{tabular}

Примітки: 1. р - вірогідність різниці показників групи хворих на гіпотиреоз з ожирінням відносно групи з нормальною масою тіла; 2. $\mathrm{p}_{1}$ - вірогідність різниці показників групи хворих на гіпотиреоз з ожирінням порівняно з контролем;

3. $\mathrm{p}_{2}$ - вірогідність різниці групи хворих на гіпотиреоз без ожиріння порівняно з контролем.

Аналіз результатів анкетування MIEФ-15 чоловіків із гіпотиреозом, ЕД та андрогенним дефіцитом виявив виражене зниження всіх показників еректильної функції в обстежених обох груп, порівняно з контрольною. Порівняння окремих показників чоловіків із гіпотиреозом залежно від маси тіла виявило вірогідне зниження більшості з них у чоловіків з ожирінням, порівняно $з$ показниками у хворих із нормальною масою тіла: досягнення ерекції, виникнення ерекції під час сексуальної стимуляції, збереження ерекції під час статевого акту, збереження ерекції до кінця статевого акту, задоволеність статевим актом, задоволення від статевого акту, частота настання оргазму, ступінь вираженості сексуально- го бажання, задоволеність статевим життям у цілому, задоволення від сексуальних стосунків із партнеркою, впевненість у досягненні та збереженні ерекції. Не виявлено вірогідної різниці між пацієнтами з ожирінням і нормальною масою тіла за такими показниками: достатність ерекції, кількість спроб здійснити статевий акт, частота еякуляцій, частота виникнення сексуального бажання.

Обчислення інтегративних показників стану статевої функції в обстежених із гіпотиреозом, андрогенним дефіцитом та ожирінням або нормальною масою тіла показав вірогідне зниження у них усіх параметрів, порівняно з контрольною групою (табл. 3). 
Огляди літератури, оригінальні дослідження, погляд на проблему

Таблиця 3. Інтегративні показники міжнародного індексу еректильної функції у чоловіків із гіпотиреозом

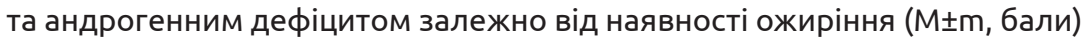

\begin{tabular}{|l|c|c|c|c|c|c|}
\hline \multicolumn{1}{|c|}{ Показник } & $\begin{array}{c}\text { Контроль } \\
(\mathrm{n}=25)\end{array}$ & $\begin{array}{c}\text { Ожиріння } \\
(\mathrm{n}=26)\end{array}$ & $\begin{array}{c}\text { Нормальна } \\
\text { маса тіла }(\mathrm{n=15)}\end{array}$ & $\mathrm{p}$ & $\mathrm{p}_{1}$ & $\mathrm{p}_{2}$ \\
\hline Еректильна функція & $26,71 \pm 0,77$ & $13,16 \pm 0,61$ & $17,26 \pm 0,53$ & $<0,001$ & $<0,001$ & $<0,05$ \\
\hline Задоволення статевим актом & $14,83 \pm 0,11$ & $7,46 \pm 0,62$ & $9,62 \pm 0,98$ & $<0,05$ & $<0,001$ & $<0,05$ \\
\hline Оргазм & $9,26 \pm 0,22$ & $5,19 \pm 0,44$ & $6,96 \pm 0,68$ & $<0,05$ & $<0,001$ & $<0,05$ \\
\hline Лібідо & $9,62 \pm 0,33$ & $7,25 \pm 0,56$ & $10,19 \pm 0,47$ & $<0,01$ & $>0,2$ & $>0,1$ \\
\hline $\begin{array}{l}\text { Загальна задоволеність } \\
\text { статевим життям }\end{array}$ & $8,98 \pm 0,43$ & $5,24 \pm 0,67$ & $5,37 \pm 0,78$ & $>0,5$ & $<0,01$ & $<0,01$ \\
\hline
\end{tabular}

Примітки: 1. р - вірогідність різниці показників групи хворих з ожирінням відносно групи з нормальною масою тіла за критерієм Стьюдента;

2. $\mathrm{p}_{1}$ - вірогідність різниці групи хворих з ожирінням, порівняно з контролем, за критерієм Стьюдента;

3. $\mathrm{p}_{2}$ - вірогідність різниці групи хворих з нормальною масою тіла, порівняно з контролем, за критерієм Стьюдента.

Більш виражене зниження інтегративних показників анкетування МІЕФ-15 в обстежених спостерігалося у пацієнтів з ожирінням. Так, середні показники еректильної функції у пацієнтів із гіпотиреозом та ожирінням були вірогідно нижчими, ніж у чоловіків із гіпотиреозом і нормальною масою тіла ( $<0,001)$, хоча показники обох груп вказують на середній ступінь ЕД. Середні показники задоволення статевим актом ( $p<0,05)$, оргазму $(p<0,05)$ і лібідо $(p<0,001)$ у чоловіків з ожирінням на тлі гіпотиреозу та андрогенного дефіциту були нижчими. Обчислення середнього показника загальної задоволеності статевим життям засвідчило виражене його зниження в обох групах, порівняно з контролем, за відсутності вірогідної міжгрупової різниці ( $>>0,05)$.

Результати й обговорення. Результати анкетування обстежених свідчать, що первинний гіпотиреоз належить до безпосередніх чинників, які погіршують статеву функцію у чоловіків. Крім порушення еректильної функції, про що свідчить зниження відповідного інтегративного показника МІЕФ-15 «Еректильна функція», в обстежених виявлено зниження як частоти виникнення, так i ступеня статевого бажання.

Андрогенний дефіцит у чоловіків з різною соматичною патологією порушує фізіологічний і біохімічний субстрати еректильної функції. Ці процеси $\epsilon$ зворотними та нормалізуються після медикаментозної компенсації дефіциту тестостерону [14]. Вважається, що поєднане ураження центральної та периферійної ланок регуляції гіпоталамо-гіпофізарно-гонадної системи у чоловіків із гіпотиреозом, надто за наявності надмірної маси тіла, пов'язано з інволютивними змінами тестикулярної тканини та кори головного мозку, атеросклеротичними процесами та впливом хронічних захворювань [15].

3 іншого боку, старіння чоловіків, як один 3 основних станів, що пов'язують із гіпотиреозом i віковим андрогенним дефіцитом, асоціюється 3 дефектом сигналу трансдукції лютеїнізуючого гормону на клітини Лейдіга, а у чоловіків з ожирінням встановлено дефект продукції тестостерону, який корелює з інсулінорезистентністю та не $\epsilon$ наслідком хронічних змін функціонального стану гіпоталамо-гіпофізарної системи [16].

Отримані дані (зниження показників еректильної функції, оргастичних відчуттів, лібідо) свідчать про наявність порушення гормональної складової регуляції копулятивного циклу в чоловіків із гіпотиреозом на тлі ожиріння.

Висновки. ЕД вірогідно частіше трапляється в пацієнтів із гіпотиреозом (у 43 із 60 чоловіків, $72,0 \%$ ), ніж у чоловіків із контрольної групи.

Встановлено вірогідне зниження всіх інтегративних показників МІЕФ-15 у чоловіків із гіпотиреозом, порівняно з показниками осіб контрольної групи.

Аналіз результатів анкетування МIEФ-15 чоловіків із гіпотиреозом, ЕД та андрогенним дефіцитом виявив виражене зниження всіх показників еректильної функції в обстежених обох груп, порівняно з контрольною. Порівняння окремих показників серед чоловіків із гіпотиреозом залежно від маси тіла виявило вірогідне зниження більшості з них у чоловіків з ожирінням, порівняно з показниками у хворих із нормальною масою тіла:

Обчислення інтегративних показників стану статевої функції в обстежених із гіпотиреозом, андрогенним дефіцитом та ожирінням або нормальною масою тіла показало вірогідне зниження у них усіх параметрів, порівняно з контрольною групою.

Перспективи подальших досліджень полягають у вивченні функціонального стану гіпофізарно-статевої системи у чоловіків, хворих на гіпотиреоз, із встановленням впливу тривалості і тяжкості гіпотиреозу, стану компенсації і тривалості еректильної дисфункції.

Конфлікт інтересів: автори повідомляють про відсутність конфлікту інтересів. 


\section{Огляди літератури, оригінальні дослідження, погляд на проблему \\ ЛІТЕРАТУРА}

1. Brody $S$. The relative health benefits of different sexual activities / S. Brody // Journal of Sexual Medicine. 2010. - No. 7. - P. 1336-1361.

2. Erectile dysfunction medications and treatment for cardiometabolic risk factors: a pharmacoepidemiologic study / S. C. Skeldon, L. Cheng, S. G. Morgan [et al.] // J. Sex Med. - 2017. - Vol. 14 (12). - P. 1597-1605.

3. Izza E. F. Definition and classification of erectile dysfunction: report of the nomenclature committee of the international society of impotence research / E. F. Izza, R. C. Rosen // Int. J. Impot. Res. - 1999. - No. 11. - P. 141-143.

4. Oyelade B. O. Prevalence of erectile dysfunction and possible risk factors amongmen of South-Western Nigeria: a population based study / B. O. Oyelade, A. C. Jemilohun, S. A. Aderibigbe // Pan. Afr. Med. J. - 2016. - P. 24-124.

5. Male sexual function in New Zealand: a populationbased cross-sectional survey of the prevalence of erectile dysfunction in men aged 40-70 years / M. Quilter, L. Hodges, P. von Hurst [et al.] // J. Sex Med. - 2017. - No. 14 (7). P. 928-936.

6. Association between erectile dysfunction and cardiovascularris kinindividuals with type2 diabetes with outovertcardiovascular disease / B. L. Meena, D. K. Kochar, T. D. Agarwal [et al.] // Int. J. Diabetes Dev. Ctries. - 2009. No. 29 (4). - P. 150-154.

7. A system aticle view of the association between erectile dysfunction and cardiovascular disease / G. Gandaglia, A. Briganti, G. Jackson [et al.] // Eur. Urol. - 2014. No. 65 (5). - P. 968-978.

8. Kaya E. A comprehensive view of metabolic syndrome affectin gerectile dysfunction / E. Kaya, S. C. Sikka,
S. Gur // J. Sex Med. - 2015. - No. 12 (4). - P. 856-875.

9. Five-year prospective studyon cardiovasculare vents, in patients with erectile dysfunction and hypotestosterone / R. Iacona, V. Bonomo, M. Di Piazza [et al.] // Arch. Ital. Urol. Androl. - 2017. - No. 89 (4). - P. 313-315.

10. Prevalence and risk factors for erectile dysfunction in Chinese adult males / X. Zhang, B. Yang, N. Li, H. Li // J. Sex Med. - 2017. - No. 14 (10). - P. 1201-1208.

11. The role of hypothyroidism in male in fertility and erectile dysfunction / M. R. Nikoobakht, M. Aloosh, N. Nikoobakht [et al.] // Urol. J. - 2012. - Vol. 9 (1). - P. 405-409.

12. Бондаренко В. О. Досвід застосування левотироксину та антиоксидантів при терапії неплідності в чоловіків, хворих на гіпотиреоз / В. О. Бондаренко, Ж. С. Співак // Міжнародний ендокринологічний журнал. 2014. - № 7 (63). - С. 35-39.

13. Keller J. Hyperthyroidism and erectile dysfunction: A population-basedcase-control study. International / J. Keller, Y. K. Chen, H. C. Lin // Journal of Impotence Research. - 2012. - No. 24 (6). - P. 242-246.

14. Grossmann M. Male androgen deficiency: a multisystem syndrome / M. Grossmann, F. C. Wu // Asian J. Androl. - 2014. - No. 16 (2). - P. 159-160.

15. The comparison of the aging male symptoms (AMS) and androgen deficiency in the aging male (ADM) question naire to detect androgen difiency in middle-agedmen / K. S. Chueh, S. P. Huang Y. C. Lee [et al.] // J. Androl. - 2012. No. 33 (5). - P. 817-823.

16. Grossmann M. Testoseterone and glucose metabolism in men: current concepts and controversies / M. Grossmann // J. Endocrinol. - 2014. - No. 220. - P. 37-55.

\section{REFERENCES}

1. Brody, S. (2010). The relative health benefits of different sexual activities. Journal of Sexual Medicine, 7, 1336-1361. doi: 10.1111/j.1743-6109.2009.01677.x

2. Skeldon, S.C., Cheng, L., Morgan, S.G., Detsky, A.S., Goldenberg, S.L., Law, M.R. (2017). Erectile dysfunction medications and treatment for cardiometabolic risk factors: a pharmacoepidemiologic study. J. Sex Med., 14 (12), 1597-1605. doi: 10.1016/j.jsxm.2017.10.063.

3. Izza, E.F., \& Rosen, R.C. (1999). Definition and classification of erectile dysfunction:reportofthe Nomenclature Committee of the International Society of Impotence Research. Int. J. Impot. Res., 11, 141-143.

4. Oyelade, B.O., Jemilohun, A.C., \& Aderibigbe, S.A. (2016). Prevalence of erectile dysfunction and possible risk factors amongmen of South-Western Nigeria: a population based study. Pan. Afr. Med. J., 24, 124. doi: 10.11604/ pamj.2016.24.124.8660. e Collection 2016.

5. Quilter, M., Hodges, L., von Hurst, P., Borman, B., \& Coad, J. (2017). Male sexual function in New Zealand: a population-based cross-sectional survey of the prevalence of erectile dysfunction in men aged $40-70$ years. J. Sex Med., 14 (7), 928-936. doi: 10.1016/j.jsxm.2017.05.011.

6. Meena, B.L., Kochar, D.K., Agarwal, T.D., \& Choudhary, R., Kochar, A. (2009). Association between erectile dysfunction and cardiovascularris kinindividuals with type 2 diabetes with outovertcardiovascular disease. Int. J.

Diabetes Dev. Ctries, 29 (4), 150-154. doi: 10.4103/09733930.57345.

7. Gandaglia, G., Briganti, A., Jackson, G., Kloner, R.A. Montorsi, F., Montorsi, P., \& Vlachopoulos, C. (2014). A system aticle view of the association between erectile dysfunction and cardiovascular disease. Eur. Urol., 65 (5), 968-978. doi: 10.1016/j.eururo.2013.08.023.

8. Kaya, E., Sikka, S.C., \& Gur, S. (2015). A comprehensive view of metabolic syndrome affectin gerectile dysfunction. J. Sex Med., 12 (4), 856-875. doi: 10.1111/jsm.12828.

9. Iacona, R., Bonomo, V., Di Piazza, M., Sansone, A., Usala, M., Novo, S., \& Pavone, C. (2017). Five-year prospective studyon cardiovasculare vents, in patients with erectile dysfunction and hypotestosterone. Arch. Ital. Urol. Androl., 89 (4), 313-315. doi: 10.4081/aiua.2017.4.313.

10. Zhang, X., Yang, B., Li, N., \& Li, H. (2017). Prevalence and risk factors for erectile dysfunction in Chinese adult males. J.SexMed., 14(10), 1201-1208. doi:10.1016/j.jsxm.2017.08.009.

11. Nikoobakht, M.R., Aloosh, M., Nikoobakht, N., Mehrsay, A.R., Biniaz, F., \& Karjalian, M.A. (2012). Therole of hypothyroidism in male in fertility and erectile dysfunction. Urol. J., 9 (1), 405-409.

12. Bondarenko, V.O., \& Spivak, Zh.S. (2014). Dosvid zastosuvannia levotyroksynu ta antyoksydantiv pry terapii neplidnosti v cholovikiv, khvorykh na hipotyreoz [Experience of levothyroxine and antioxidants in the treatment 
Огляди літератури, оригінальні дослідження, погляд на проблему

of infertility in men with hypothyroidism]. Mizhnarodnyi endokrynolohichnyi zhurnal - International Endocrinology Journal, 7 (63), 35-39 [in Ukrainian].

13. Keller, J., Chen, Y.K., \& Lin, H.C. (2012). Hyperthyroidism and erectile dysfunction: A population-based casecontrol study. International Journal of Impotence Research, 24 (6), 242-246. DOI: 10.1038/ijir.2012.24.

14. Grossmann, M., \& Wu, F.C. (2014). Male androgen deficiency: a multisystem syndrome. Asian J. Androl., 16 (2), 159-160.
15. Chueh, K.S., Huang, S.P., \& Lee, Y.C. (2012). The comparison of the aging male symptoms (AMS) and androgen deficiency in the aging male (ADM) question naire to detect androgen difiency in middle-agedmen. $J$. Androl., 33 (5), 817-823.

16. Grossmann, M. (2014). Testoseterone and glucose metabolism in men: current concepts and controversies. J. Endocrinol., 220, 37-55.

\section{СОСТОЯНИЕ ЭРЕКТИЛЬНОЙ ФУНКЦИИ У МУЖЧИН С ПЕРВИЧНЫМ ГИПОТИРЕОЗОМ}

ФН. В. Пасечко, Т. И. Крицкий, Л. В. Наумова

Гвуз «Тернопольский государственный медицинский университет имени И. Я. Горбачевского МЗ Украины»

РЕЗЮМЕ. Одним из наиболее частых общих хронических расстройств у мужчин после 40-летнего возраста является эректильная дисфункция (ЭД) - неспособность достичь и/или поддерживать эрекцию полового члена, достаточную для осуществления удовлетворительного полового акта.

Цель исследования - оценить эректильную функцию по шкале «Международный индекс эректильной функции - 15» у мужчин с первичным гипотиреозом, которые находились на стационарном и амбулаторном лечении в Тернопольской университетской больнице.

Материал и методы. Анализ состояния эректильной функции у мужчин с гипотиреозом проводили с использованием опросника «Международный индекс эректильной функции - 15" (МИЭФ-15). Обследовано 60 мужчин с первичным гипотиреозом в возрасте от 21 до 75 лет.

Результаты. ЭД достоверно чаще встречается у пациентов с гипотиреозом (43 из 60 мужчин, 72,0 \%), чем у мужчин из контрольной группы. Установлено достоверное снижение всех интегративных показателей МИЭФ-15 у мужчин с гипотиреозом, в сравнении с показателями лиц контрольной группы. Результаты анкетирования обследованных больных указывают на гипотиреоз как на прямой фактор, отрицательно влияющий на половую функцию у мужчин.

Выводы. Анализ результатов анкетирования МИЭФ-15 мужчин с гипотиреозом, ЭД и андрогенным дефицитом выявил выраженное снижение всех показателей эректильной функции у обследованных обеих групп, в сравнении с контрольной. Вычисление интегративных показателей состояния половой функции у обследованных с гипотиреозом, андрогенным дефицитом и ожирением или нормальной массой тела показало достоверное снижение у них всех параметров, сравнительно с контрольной группой.

КЛЮчЕВЫЕ СЛОВА: первичный гипотиреоз; эректильная дисфункция; ожирение.

\section{STATE OF ERECTILE FUNCTION IN MEN WITH PRIMARY HYPOTHYROIDISM ON. V. Pasiechko, T. I. Krytskyy, L. V. Naumova I. Horbachevsky Ternopil State Medical University}

SUMMARY. Erectile dysfunction (ED) as inability to attain and/or support penile erection sufficient for realization of satisfactory sexual intercourse in men after 40 -years-old age is one of the most frequent general chronic disorders.

The aim of the study - to estimate an erectile function on a scale «The International index of erectile function (IIEF) - 15» for men with a primary hypothyroidism, that were on stationary and ambulatory treatment in Ternopil University Hospital.

Materials and Methods. Analysis of the state of erectile function in men with hypothyroidism conducted the "The International index of erectile function - 15» (IIEF). 60 men with primary hypothyroidism in age from 21 to 75 years were under observation.

Results. ED was significantly more often meets in patients with hypothyroidism (43 of 60 men, $72.0 \%$ ), what in men from a control group. The significant decrease decline of all integrative indexes of IIEF-15 was set in men with hypothyroidism by comparison to the indexes of patients in control group. The results of questionnaire of the inspected patients specify on hypothyroidism as on a direct factor that negatively influences on a sexual function in men.

Conclusions. An analysis of results of IIEF-15 questionnaire in men with hypothyroidism, ED and educed the expressed decline of all indexes of erectile function and androgen deficiency at inspected both groups by comparison to control. Calculation of integrative indexes of the state of sexual function in inspected men with hypothyroidism, significant decrease showed an androgen deficiency and obesity or normal body weight for them all parameters comparatively with a control group.

KEY WORDS: primary hypothyroidism; erectile dysfunction; obesity. 